Nordic Journal of Modern Language Methodology

(NJMLM)

(1)

\title{
John Stewart and Stephen Colbert as Jesters in King Harald's Court: Relying on Heavily Humor when Teaching English at Home and Abroad
}

\author{
by Colin Irvine
}

It had been fourteen years since I had last stood in front of a group of high school students for the purposes of teaching English, and now here I was again...only this time I was not standing so much as flailing, or, more accurately, falling. And I was doing so dramatically, accompanied by a flock of fluttering $3 \times 5$-inch note cards that had taken flight when my outstretched hand had brushed past the corner of the teacher's desk on which I had previously placed my neat stack of notes.

Having stepped out into the hall seconds before class began in order to gather myself, I had when re-entering the room intentionally hooked my left foot on the leg of a large tripod standing just inside the doorway. Half of a stride later I was stumbling in the direction of what looked to be a group of vaguely confused students in this high school in Sandnes, the first of many such venues I would be visiting during my time as a Fulbright Roving Scholar in Norway for the 2010-2011 academic year.

The Roving Scholar Program is a unique Fulbright that exists only in Norway. It involves two Upper-Secondary "Rovers" (who teach in the videregående skoles) and one LowerSecondary "Rover" (who works in the ungdomsskolen). The three Rovers post on the web in the summer before the school year begins abstracts of their presentations (of which there are between 8-12 per person, some focusing on American Studies topics and others on teaching methods and related educational issues); then, teachers and administrators from schools throughout the country contact the Rovers, invite them to their schools, and, when doing so, request particular presentations and workshops. 
This arrangement means that one seldom teaches in the same school twice, and it likewise means that it is nearly impossible to be certain when walking (or stumbling) into a classroom what the students and teachers know or do not know before you begin talking with them about topics pertaining to American literature, history, politics, media, popular culture, and pedagogy. These, to be sure, are challenging circumstances under which to teach, and they are made more so by the added uncertainty that comes with not knowing how well the students and their instructors will understand English, their second language, and thus how likely they will be to participate in various classroom activities. For these reasons and countless others, I was on min første dag på jobben, more than a little anxious as I came skidding to a halt a few feet in front of the first row of student desks.

Lying there face down on the floor hoping my risky stunt had work, I waited for the laughter and then, after a brief and painful pause, it came. In fact, every person in the room including the teacher, in spite of herself it seemed - started chuckling, some doing so discreetly and others more shamelessly. What a relief, I thought as I stood up, brushed myself off, and playfully accused everyone with the question, “OK. Who laughed?" They all they raised their hands.

After a few weeks of performing this acrobatic opening, I began to switch up my hook a bit, moving away from the staged (and dangerous) pratfall to something a little more conventional. I did so for a couple of reasons. First, I decided the gag was not worth the stress of furtively setting it up and convincingly pulling it off. (One teacher from a school that will go unnamed, was struck with chest pains when she saw me trip and fall, and another - a considerate and attentive woman who had come out of retirement to serve as a substitute - was too meticulous to trick: four separate times before class began she moved the tripod out of the walkway and as many times she relocated my stack of note cards safely in the middle of the teachers' desk.) Second and much more importantly, I moved away from this opening bit because the focusing questions at the core of my presentation had, after engaging the Norwegian students and their teachers, changed out from underneath me.

I spent several months prior to my move to Norway developing a workshop designed to help the Norwegian students appreciate and apply core Bakhtinian ideas regarding the ways that 
humor helps create and perpetuate irreverent discourse communities (Ramazani 12) that nurture democratic ideals (Moi 40). I tried initially to underline for the students the contention that, according to the authors of Satire TV: Politics and Comedy in the Post-Network Era, "humor is something that encourages criticism and reflection about prevailing systems of power, and it can be a discursive tool used by both [political] parties in a struggle between dominant and resistant forces" (Gray et al. 10). To these ends, I set out each time I taught to convert the classroom into a kind of analogue for the United States: I encouraged the students to laugh at me in order that they might recognize at the outset of the workshop that I, as the alleged authority, am reduced by and through laughter, that we are all equals, and that anything is possible in a classroom or country open to the unpredictability that invariable attends humor.

Relying heavily on humor in general and the element of surprise in particular when introducing the students to American literature meant that I needed as a teacher and researcher to be open to other issues and questions that might arise while working in the classroom with students. And, fittingly, I soon found midway through the fall semester that I was focusing in my preparations less on questions regarding humor and its role in American culture and more on the reception of these ideas in foreign classrooms and, specifically, alien minds. Anxious about how well the lessons were hitting the mark, I became increasingly intent on wrestling with what were more pedagogical and, in this new context, pressing questions. To begin with, I wanted to know if the students were "getting it." Was there a way, I wondered, to be sure they understood the "semantic complexity" connected with comedy and its place in American texts (Hutcheon 4)? Along similar lines, I wanted to know what, in the framework of a classroom in another country, it means to "get" literary, indirect humor. I likewise was curious to determine and possibly develop ways, beyond laughter, that these students could show and share their understanding of the content in question (Gorham and Christophel 46-62) .

Thus, guided by a heightened interest in the intersection between humor studies and pedagogy, I soon went away from my pratfall and began instead to open up the workshop on reading humorous texts with an excerpt from the video of Stephen Colbert roasting President Bush at the White House Correspondence dinner in 2006. Doing so served my original objectives as well as my new ones while at once saving me the trouble of having to stretch before 
teaching. And in terms of instructions for viewing the text, I asked the students to watch the video and to consider how they might feel if they had been in the audience while at once trying to determine on whom are the jokes. Then I played the clip and studied their responses, something relatively easy to do despite the language barrier because evidence of understanding came in the form of smiles and laughter (and, in some instances, uncomfortable shifting in seats).

Again, as was the case when I would fall to the floor, the students almost always laughed during these all-important opening moments of class. And what struck me when I analyzed these Scandinavian teenagers and their teachers watching Colbert enjoy himself at President Bush's expense was just how many of the numerous and subtle comments by and about Americans they most definitely understood.

However, despite having this audible, apparent evidence of understanding, I still had no way of talking about what occurs when - with the help of comedians, teachers, and other nimbleminded observers of society - people perform the kinds of cognitive gymnastics required to comprehend satire until I came across John Frow's essay “The Literary Frame,” which provides a model for what happens in the classroom and in the mind where humor is at the center of the interpretive exchange. As Frow explains, "The function of aesthetic closure which marks off literary space is to establish the particular historical distribution of the 'real' and the 'symbolic' within which the text operates. The border of the text constitutes and defines its specific fictional status" (25). This "frame" separates literary space from historical, "real" time/space and thus designates a "limit" that is "at once material and immaterial, literal and figurative, between adjacent and dissimilar ontological realms" (25). Published in 1982, Frow's notion regarding the separation of framed narratives from the world they inhabit has held sway for years; however, I would contend that more contemporary, media-based texts common in the lives of our students are both separate from the ontological, empirical world and simultaneously, essentially a part of it as well, a fact not lost on teens who reside comfortably in our postmodern world of an overlapping, highly intra-textual world.

The "comedic situations" common to the contrived videos in programs such as The Daily

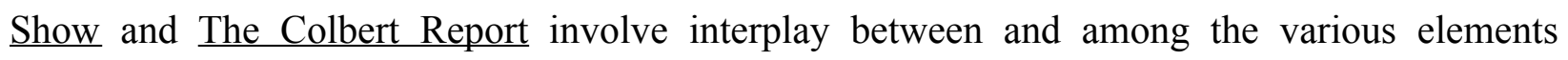
(meaning the characters, the setting where the scene unfolds, the studio audience, the original 
television viewers, the subsequent ones, online bloggers, and, impressively, the world in the form of the "world wide web") and the space/times connected with all of those elements. A joke, for instance, can originate in the context of a faux report by Wyatt Cynac or Jason Jones, allude to something beyond her or his realm in the real world of Rick Perry or Congressman Anthony Weiner, and, in the end, elicit the viewer's laughter because of something said or done subsequently or previously in altogether separate but related contexts. Humor, in other words, is as spatial as it temporal, as much about context as it is about timing.

And because of the myriad of ways that technology allows for such media techniques as split screens, voice-overs, and montages accompanied by music, even the briefest of comedic sketches often represent chaotic intersections of references involving images and allusions from other time/spaces. Further, as Noel Carroll has explained in reference to postclassical Hollywood films, creators of popular culture - including televised comedies - "brought up on TV and trained in film schools" rely heavily on references to other, extant forms of culture, including films, music, international news events, sports, etc. (262). The result are texts that speak to numerous audiences simultaneously, including to "newly hip" viewers who appreciate the offhand allusions, the un-initiated who do not, those viewers watching with laptops at the ready eager to connect the dots between what they are seeing and hearing while watching and what it links to on the increasingly a-temporal web (Bordwell 7) - and, finally, foreigners who fit into any number of these groups.

Given the somewhat convoluted nature of these situations wherein satirists make multiple and often ironic references requiring that viewers be familiar with any number of people, events, etc., in order to appreciate the implied point, I was - especially under the circumstances - eager to develop a teaching technique that would enable the Norwegians to show what they understood about the comedy/content and the situation(s) in which it occurs. Also, because it can be an unreliable measure of who "gets" what, I wanted to move away from relying heavily on laughter as the best indicator for assessing understanding. Further, given the fact that I was dealing on nearly a daily basis with famously restrained Norwegians, I knew that I needed to come up with something that relied less on words and more on images if I were to have a chance at succeeding. Guided by these goals, I designed an activity that invited the students to study short videos from 
The Colbert Report and The Daily Show and then diagram their understanding of what was happening in the exchanges between and among comedians, guests, studio audiences, and others on the giving and/or receiving end of the satire. Despite the challenges that attend this kind of analysis, and despite what the authors of Satire TV: Politics and Comedy in the Post-Network Era make clear, namely that, "Satire demands a heightened state of awareness and mental participation in its audience (not to mention knowledge)" (Gray et al. 1), the students, it turns out, had little difficulty appreciating the satire, understanding its multidirectional characteristics, and re-presenting through pictures their particular interpretations.

One clip I often played involves an interview with environmental activist Bill McKibben on The Colbert Report (2) and another, titled "The Money Honey Bee," appeared on Monday, March 16, 2009 on The Daily Show and features "correspondent" Samantha Bee interviewing traders from investment firms who short-sell companies during bearish markets (3). Both videos underlined the subtle but striking ways that satire spirals out from an original premise/place into other enveloping frames by way of allusions and offhand references while recursively looping back into the primary one for couched punch lines and audible laughter.

Figure 1 below shows the students' rendition regarding what took place on The Colbert Report during an interview involving Colbert and environmentalist Bill McKibben. 
Figure 1 Picture drawn by students at Foss VGS: Colbert Show 1

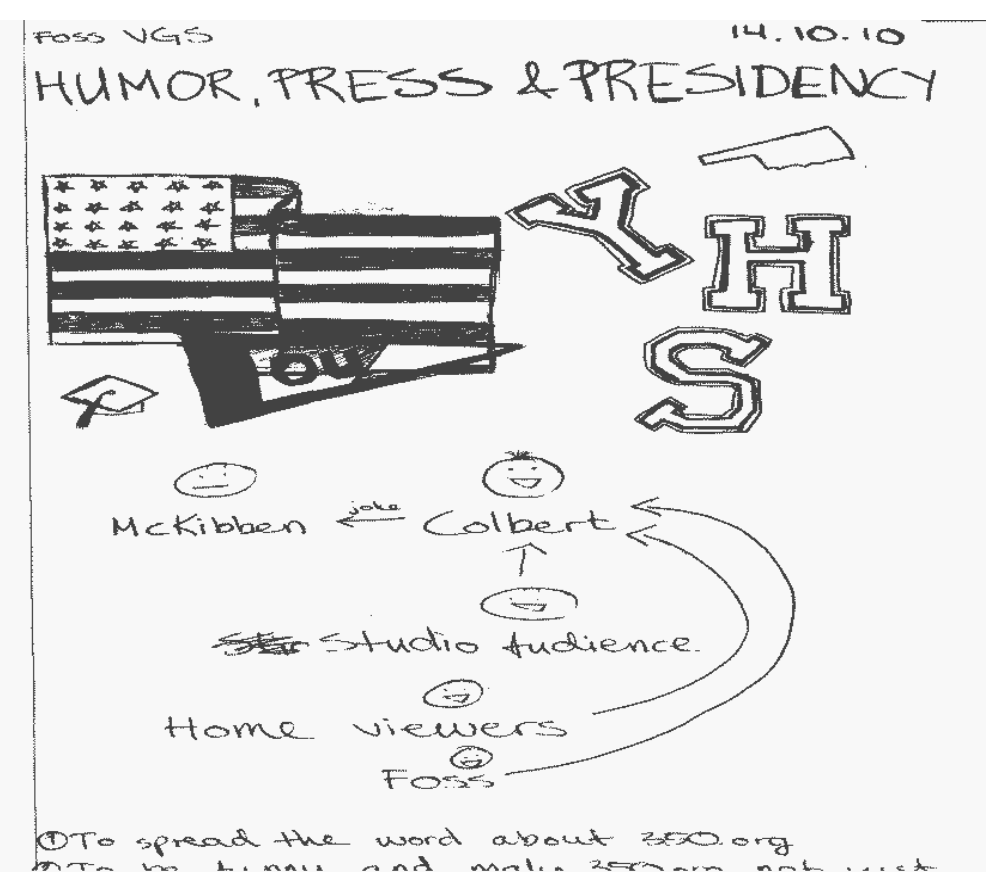

It demonstrates the students' use of smiley-face icons and arrows to present their interpretation of the exchange between the host and the guest.

Not surprisingly, one frequent feature of the student illustrations were boxes, or frames. (See figure 2) One of the groups at Foss, for instance, used nested frames (Marie-Laure Ryan 369-371) to outline the separate but intersecting agents who participate in a highly dialogic event such as the one that unfolds during the video clip. In this regard, the illustrations underscore the students' command of what Hutcheon describes as "the conditioning role of contexts" (4). Interestingly, the students conveyed a clear appreciation of the original and subsequent event, noting the overlapping discourse communities that include Colbert and McKibben, home viewers in the States (of both political parties), and the students themselves in Norway. 
Figure 2 Picture drawn by students at Foss VGS school: Colbert Show 2

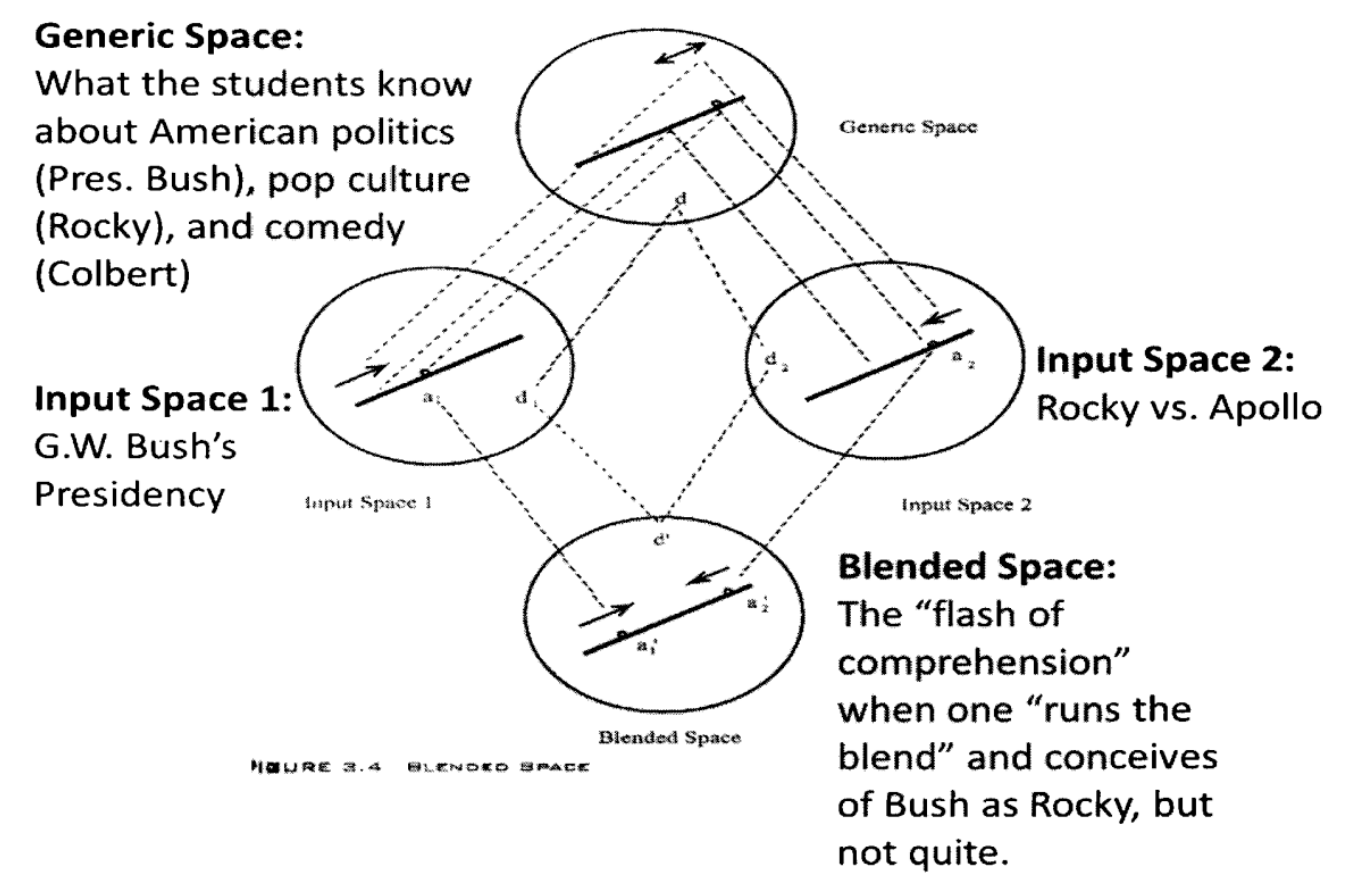

Another group, when discussing The Daily Show's Samantha Bee and her piece on shortselling used simple but effective drawings involving boxes, arrows, and faces. (See figure 3)

Figure 3: Picture drawn by students at Foss VGS: The Daily Show 


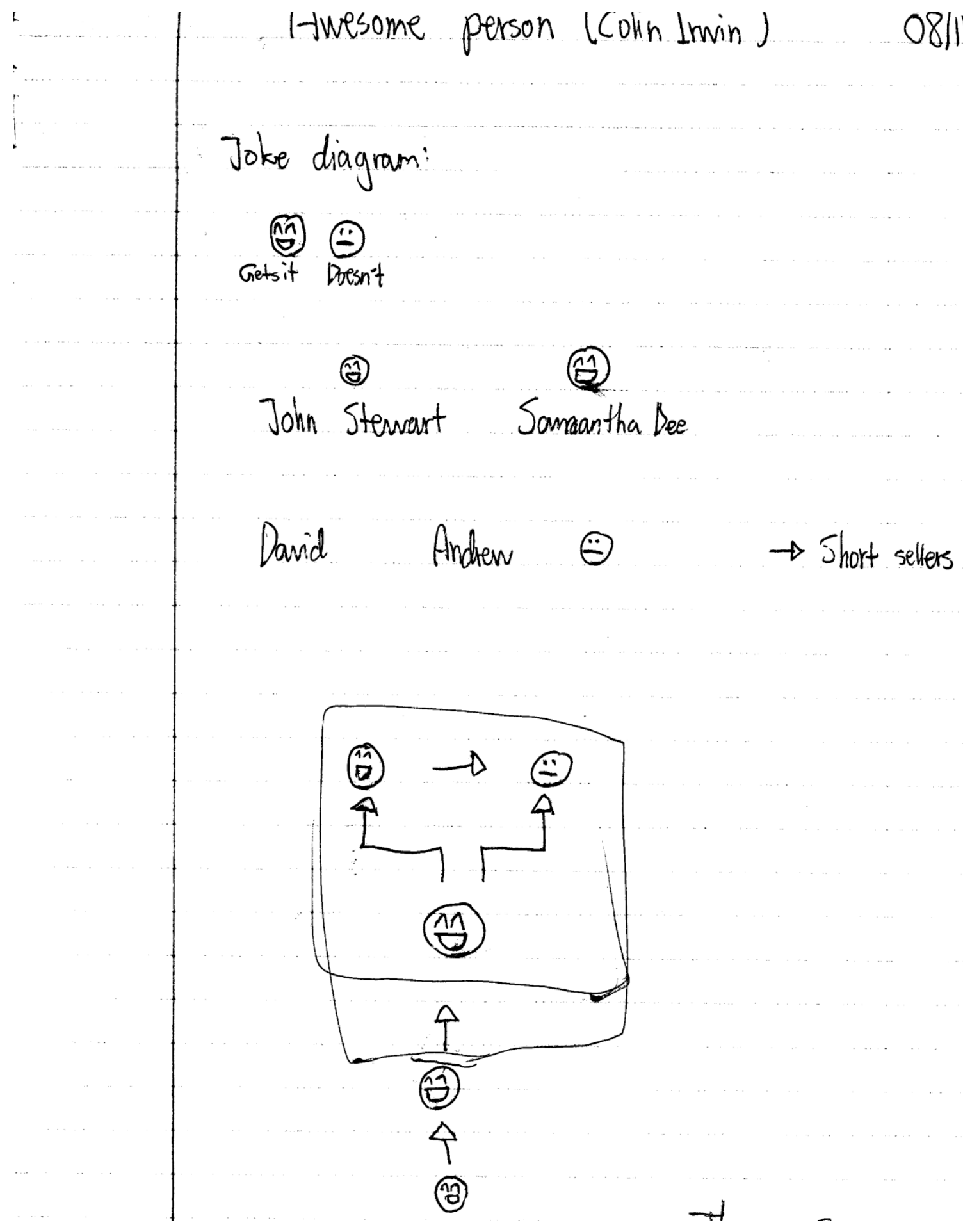

These drawings indicate the students' appreciation of how the irony was lost on the interviewee but not on the "correspondent," the host or the studio audience. Further, given the drawing's depiction and what it reveals, this misdirection did not escape the notice of these students either. 
Their illustration shows their sophisticated command of the intellectual ideas connected with discourse communities and exchanges.

This last point regarding the groupings specific to each video acted as a bridge to a more intangible idea I focused on in my lesson concerning how humor functions in societies large and small. As I pointed out to the students, on the surface (and in many of their illustrations), satire, parody, irony, and other forms of humor appear at first blush to be self-contained and therefore mostly innocuous: if you are not on the receiving end of the humor, then - it seems - you are relatively safe. Or, closer to home for these students, if you are not the person falling to the floor or the one being roasted at an event, you have no need to worry. This contention, of course, draws on Bakhtin's insistence that "laughter (reduced to irony) [...] bring[s] the world closer and familiarizes" it so that we can "investigate it fearlessly and freely" (25). That said, the main point I tried to make when reviewing the clips and diagrams was this: if no one is completely safe, then everyone is at some risk. Hence, a country that allows comedians to criticize sitting presidents and other politicians as well as all others who wield power is one that - like a classroom that cultivates playfulness and laughter, even at the teacher's expense - insists on surprise and egalitarianism (Askildson 2005).

\section{Irony as a Cultural Barometer in English Classrooms at Home and in Other Countries}

Near the end of my time as a Roving Scholar, in a fit of non-Norwegian modesty, I was tempted to conclude based on my positive experiences with the students that I had helped to create the playful and intellectually stimulating classroom environments that enabled the students and teachers to understand better American humor in various genres. In reality, I had merely entered into already well-informed communities comfortable enough with the topics at hand to laugh at often uncomfortable comments and remarks. I did not, in essence, create or inspire discursive learning communities that could comprehend American humor but instead employed irony, satire, and other forms of humor to prove Hutcheon's contention that, "It is the overlapping of some of the communities of ironist and interpreter that sets the stage for the transmission and reception of intended ironies" (1995 20). 
In view of this situation, the ideas about humor and its role in American society (and Norwegian classrooms) proved approachable and even applicable for nearly all of the Norwegians with whom I had the good fortune of working closely during the year that I traveled the country delivering the workshop, "Humor, Press, and the Presidency," one I gave a total of 37 times in 22 different schools to almost 2,000 students and teachers. In fact, I found that vocational students in Lofoten training to be plumbers, Sami students in Karasjok preparing to enter into politics, and even athletes in Grong gearing up for careers in sport fishing could readily grasp, for example, the notion that - when it comes to analyzing humorous texts - "no one is safe," to quote the emcee who presciently introduced Stephen Colbert at the 2006 White House Correspondents' Dinner. What I did not initially understand, however, was the extent to which the type of discourse community required to appreciate the humor I was presenting actually preceded my visits to the classrooms.

Given the fact that - due to technology as well as other factors - each of us as citizens of the world belongs to more and more semantic communities (many of which, oddly enough, are getting smaller), we are increasingly encountering one another in "contact zones" (Pratt 1991 34) that have less in common with older, more traditional discourse communities, an idea that literary studies helps illuminate. Soon, perhaps, our students will identify more with others according to common cultural texts (non-news news shows, viral videos, Facebook, etc.) and less with those with whom they share physical space and similar political and historical background; and it will be through literary studies and especially a close eye on irony that we can continue to measure the rise of these uniquely modern communities and their increasing overlap on the web and elsewhere. Accordingly, while my classroom successes throughout Norway in some measure speak to the pervasive nature of American culture around the world, they likewise underscore how well humor serves as a kind of cultural barometer, one that illuminates the increasing overlap between America and other countries and their (dis)respective cultures and discourse communities.

Finally, having now returned to the States and begun to teach American Studies to American students, I am finding that much of what I discovered about humor's role in educational discourses communities while abroad applies to what I am doing here at home. 
When I as a teacher am able to be ironic, for instance, when talking with students about certain topics, I can be confident that the members of my class are sufficiently prepared to engage these subjects and texts in ways that are imaginative and critical (and playful). And although some of my students may, like their Norwegian equivalents, lack certain academic-level language skills associated with reading and writing Standard American English, this does necessarily (or is even likely to) indicate an inability or unwillingness to comprehend and even analyze a wide range of problems and texts pertaining to American culture... "which is nice," to borrow a fitting phrase from Carl Spackler of Caddyshack fame, my personal patron saint of humor studies. 


\section{Works Cited}

Askildson, Lance. "Effects of Humor in the Language Classroom: Humor as a Pedagogical Tool in Theory and Practice.” The Arizona Working Papers in Secondary Language Acquisition \& Teaching 12 (2005): 45-61.

Bakhtin, M.M. The Dialogic Imagination: Four Essays. Trans. Caryl Emerson and Michael Holquist. Ed. Michael Holquist. Austin, Texas: University of Texas Press, 1981.

"Bill McKibben Interview." August 17, 2009. The Colbert Report. Comedy Central. Episode 05112.

Bordwell, David. The Way Hollywood Tells It: Story and Style in Modern Movies. Berkeley, California: University of California Press, 2006.

Carroll, Noel. "The Future of Allusion: Hollywood in the Seventies (and Beyond). Interpreting the Moving

Image. Cambridge: Cambridge University Press, 1998.

Chambers, R. "Irony and the Canon.” Profession 90 (1990): 18-24.

Frow, John. “The Literary Frame.” The Journal of Aesthetic Education 16:2 (1982): 25-30.

Gorham, J., and Christophel, D. M. “The Relationship of Teachers' use of Humor in the Classroom to Immediacy and Student Learning." Communication Education 39 (1999): 46-62.

Gray, Jonathan, Jeffrey P. Jones, and Ethan Thompson, eds. Satire TV: Politics and Comedy in the Post-Network Era. New York: New York University Press 2009.

Hutcheon, Linda. Irony's Edge: The Theory and Politics of Irony. London: Routledge, 1995.

Moi, Toril. Sexual/Textual Politics, London and New York: Methuen,1985.

"Money Honey Bee." March 16, 2009. The Daily Show with Jon Stewart. Comedy Central. Episode 14037.

Nelles, William. "Stories within Stories: Narrative Levels and Embedded Narratives," Studies in the Literary Imagination 25.1 (1992):

Ramazani, V.K. The Free Indirect Mode: Flaubert and the Poetics of Irony. Charlottesville: University Press of Virginia, 1988.

Ryan, Marie-Laure. “Stacks, Frames, and Boundaries,” Poetics Today 11.4 (1990): 873-899. 